\title{
Teaching Reading Techniques and Strategies English Language
}

\author{
Melissa Marchiani Palone Zanatta ${ }^{1}$, Albertina Laufer $^{2}$, \\ Cláudio Maximiliano Zaina ${ }^{3}$ \\ ${ }^{1,3}$ Federal Institute of Education, Science and Technology of São Paulo \\ campus of Presidente Epitácio
}

${ }^{2}$ UNINTER International University Center

\begin{abstract}
This article aims to present the reading techniques and strategies in the teaching of the English language applied to students of the technical course of computer science integrated to high school at the Federal Institute of Education, Science and Technology of São Paulo campus of Presidente Epitácio. The methodology adopted, focusing on the instrumental approach, involved face-to-face classes, with activities carried out in pairs and individuals, allowing the development of a relevant and significant teaching-learning process. The applied and described techniques are the recognition, in the text, of cognate words and known words; skimming; scanning; the search for keywords, repeated words and typographical clues; critical reading, nominal groups; contextual reference; affixes and the general idea of the text. The strategies used and presented are: content prediction; contextual inference and selectivity. The results obtained show that the learning objectives were achieved, since the students, even without having knowledge of the language, managed to extract the central idea of a text.
\end{abstract}

Keywords: technical English, competence, extract, learning; activities

\section{Introduction}

The term instrumental English is part of a movement in the area of foreign language teaching called "Language for Specific Purposes" (LSP). This movement covers the teaching of any foreign language according to the specific needs of the student (CELANI et al, 1988).

In Brazil, English for Specific Purposes (ESP) became known as "Instrumental English" due to the initiative of PUC / SP to create the National Project for Teaching Instrumental English in Brazilian Universities, originally coordinated by professor Maria Antonieta Alba Celani, with the support of the British Council (ROBINSON, 1980). Several seminars were organized for teachers in Public Universities and Federal Technical Centers, in the 70's, in order to carry out training to prepare them for teaching the English language in addition to the production of didactic material. 


\section{2nd World Conference on Teaching and Education}

\section{9-21 February, 2021 Vienna, AUSTRIA}

Based on this demand, the instrumental English discipline was included in the curriculum of many university courses, prioritizing mainly the ability to read in the teaching-learning process through reading strategies to enable students to read and understand academic texts in different areas.

According to the National Curriculum Parameters (PCNs), with regard to foreign language teaching, pedagogical guidelines and instructions for working with reading and textual comprehension are presented (BRASIL / SEMTEC, 2002).

Lima (2009) considers that the ability to read, when well developed, is a tool for students to exercise their citizenship with more property and starts to put reading comprehension in English as one of the main objectives to be achieved.

Textual comprehension is an activity with specific purpose and objectives, such as listening to a song, reading a newspaper, listening to a news item on the radio, understanding an explanatory text about the rules of a game, reading a medicine leaflet, etc. (BRASIL, 1998). The classes were therefore directed to the academic and motivational development of the student. For academic development a schedule of classes was made, with each class explaining a reading strategy followed by its application in understanding a text with subjects related to the different areas. The approach, regarding motivational development, was in relation to the teacher producing more dynamic classes for the students' interaction and participation.

In the next section, reading strategies are presented so that other teachers can use them in order to increase student understanding of various texts, especially in the technical area, in addition to developing knowledge about grammatical aspects of the English language, with the aim of reading communication in English.

\section{Body Reading Techniques and Strategies}

The teaching of reading, by means of strategies, facilitates the construction of meaning in the text, since they are skills used to promote comprehension and reading, characterized by being flexible plans for readers, who in fact seek to achieve desired goals and objectives in the text (SANTORUM, SCHERER, 2008). Reading a text, making sense of it, commenting, listening to other people's opinions about the same text and rereading are actions that teachers can and should develop with students of different age groups.

Reading techniques and strategies can help readers learn a little about reading and improve reading in English. However, understanding the text read does not depend only on vocabulary knowledge. It depends on the reader's ability to relate ideas, establish references, make inferences or logical deductions, identify keywords, in addition to signaling repeated, known words that have some meaning, such as prefixes and suffixes, for example.

According to Jacobs (2003), some tips for exploring an English text would be: - not to read word for word; - use your prior knowledge on the subject; - know and use reading techniques and strategies; - pay attention in context; - seek to learn grammar and verbs.

In the next sections, some reading techniques and strategies used in instrumental modality and applied in high school are presented. 


\section{2nd World Conference on Teaching and Education}

19-21 February, 2021

Vienna, AUSTRIA

\subsection{Scanning}

The translation of the word scan in Portuguese is to sweep, examine, explore. On purpose, the name of the scanning technique is because the reader has to scan the text to examine details and objective ideas.

This reading technique should be used when it is necessary to find specific information in a text, for example, the address of a store in the phone book. The reader searches for the store's name, in alphabetical order, until it finds it to write down the address. It is the same technique used when the reader reads the headlines of a newspaper looking for a subject that interests him (ESTRATÉGIA VESTIBULARES, 2020).

The scanning technique involves reading from top to bottom, looking for keywords, specific phrases or ideas. It is also important to search for words in bold, italic, font sizes or different colors.

After "scanning" the text, the reader must use the skimming technique, presented below.

\subsection{Skimming}

The English word skim is translated by gliding to the surface, passing the eyes. It is a reading technique that aims to obtain only the general idea, for example, when the reader looks at a newspaper to decide which article, ad or news to read.

The skimming technique is more comprehensive than the scanning technique, as it requires knowledge of text organization, perception of vocabulary tips, ability to infer ideas and other more advanced reading skills.

The use of skimming is frequent when the reader has a lot of material to read in a short time. Generally, skimming reading is performed 3 to 4 times faster than normal reading.

There are many techniques that can be used when performing skimming, such as (STRATEGY VESTIBULARES, 2020): - reading the first and last paragraph using titles, summaries and other organizers as they read the text; - read the title, subtitle, headings and illustrations; - read only the first sentence of each paragraph; - find dates, names, places; review figures and tables.

The techniques of reading scanning and skimming are often considered research techniques. However, when it is necessary to read long texts, they are practical and useful.

\subsection{Identification of cognate words}

Cognates are the same or similar words in the spelling with the words in Portuguese and have the same meaning. They help to extract the main subject of a text. The words that people know also help and, many times, people confuse them with cognates. There are also false cognates, which are the same or similar words in the spelling with the words in Portuguese, but with different meanings. For example: date in English, means data in Portuguese.

The cognate words represent 25\% of an English text (CIOCARI, 2011/2) and, therefore, is a significant technique.

Some cognates are shown in Table 1. 


\section{2nd World Conference on Teaching and Education}

Table 1: Cognate words.

\begin{tabular}{|r|c|}
\hline words & meaning \\
\hline activity & atividade \\
\hline banana & banana \\
\hline car & carro \\
\hline different & diferente \\
\hline exercise & exercício \\
\hline future & futuro \\
\hline important & importante \\
\hline material & material \\
\hline minute & minutos \\
\hline positive & positivo \\
\hline question & questão \\
\hline television & televisão \\
\hline telephone & telefone \\
\hline video & video \\
\hline (MUNDO
\end{tabular}

\begin{tabular}{|c|c|}
\hline words & meaning \\
\hline accidental & acidental \\
\hline comedy & comedia \\
\hline criation & criação \\
\hline comic & cômico \\
\hline competition & competição \\
\hline composition & composição \\
\hline emotion & emoção \\
\hline garage & garagem \\
\hline human & humano \\
\hline ideia & ideia \\
\hline mission & missão \\
\hline music & música \\
\hline offensive & ofensivo \\
\hline potential & potencial \\
\hline
\end{tabular}

(MUNDO VESTIBULAR, 2020).

\subsection{Identification of repeated words and typographical tracks}

Repeated words appear especially in the form of verbs, nouns and adjectives and are not always cognate, but are usually important for understanding the text.

Often, in order not to repeat the same term, the author uses synonyms of the same words so as not to make the text tiresome and repetitive.

Typographic cues are elements that, in the text, convey information that is not always represented by words, which can be figures, tables, dates, numbers, graphs, among others (INFOESCOLA, 2020).

Some writing resources are also considered typographic cues, such as quotation marks, ellipsis, parentheses, bold, italics. Recognizing them is a very useful aid to reading.

\subsection{Identification of keywords and text general idea}

Keywords are the main search engines. They can appear repeatedly and sometimes in the form of synonyms. Identifying the keywords through the skimming strategy can lead the reader to have an overview of the text (BENDITO INGLÊS, 2020). 


\section{2nd World Conference on Teaching and Education}

\section{9-21 February, 2021}

Vienna, AUSTRIA

The general idea of a text is obtained using previous strategies. By carefully selecting some words, terms and expressions in the text, one can arrive at the general idea of the text.

It is possible to reach a conclusion about a certain text even without having much knowledge of English. It is clear that as the reader is practicing and learning, the perception of the text will also increase. There is a lot of information that is not so obvious.

\subsection{Critical reading}

The critical understanding of the act of reading, according to Paulo Freire's conception, does not end with the decoding of the word or written language, but implies the perception of the relationships between the text and the context, as language and reality are dynamically linked (FREIRE, 1988).

Critical reading work represents an extension of the students' expectations of critical development. Critical reading does not have the main objective of including suggestions for changes in the text, it only interprets it, trying to answer some questions such as: - is the title adequate in relation to the text content? - is the title attractive ?; - is the subject original ?; was the text presented in an objective manner ?; - does the reader agree with the author's ideas ?; - what is the text genre ?; - when and where was the text written ?; among others (BENDITO INGLES, 2020).

These questions aim to make the student, together with the teacher, analyze the text as a whole. As a suggestion, teachers can prepare a questionnaire to find out what the needs and interests of students are and apply it at the beginning of the school year.

\subsection{Nominal groups}

Nominal groups are groups of words formed by a noun (nucleus) and one or more modifiers, which can be adjectives or other nouns (BENDITO ENGLÊS, 2020).

In Portuguese, the order is generally core + modifier, such as: hot dog. In English, the order will be reversed: modifier + core, like hot dog. The adjective hot, therefore, changes the meaning of the noun dog. Generally, the nucleus of the nominal group will be the last word of the group.

When interpreting texts, it is important to read the sentence until the end, especially if you are translating nominal groups and they are composed of many words. One tip is to start translating from right to left. As an example, consider the phrase: Environmental studies classes. The adjective is environmental; the noun with the function of adjective is studies (studies) and the noun is classes (classes). Translation is environmental studies classes.

\subsection{Contextual reference}

Contextual reference are elements used in the text to provide coherence through links between the reference elements and something that has been mentioned previously. This avoids repetition of terms that make reading tiring and confusing in terms of understanding (OLIVEIRA and ROLIM, 2012).

These elements appear in the form of pronouns (I, you, he, she, it, you, we, they), adjectives (my, your, his, her, its, your, our, their) and the defined article (the), indefinite 


\section{2nd World Conference on Teaching and Education}

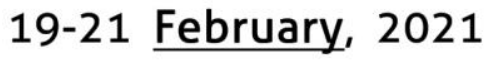

Vienna, AUSTRIA

articles (a, an) the prepositions (in, on , at, for, to) and conjunctions (and, but, although, because, each and since).

\subsection{Affixes: prefixes and suffixes}

Affixes consist of one or more letters that are added to the beginning or end of a word, which can be (ENGLISH 200H, 2020):

- prefixes: when they are added to the beginning of words. For example: ir, in meaning not (irregular; incapable);

- suffixes: when they are added to the end of words. For example: ed, er meaning pass of regular verbs and person that to do (walked; writter).

\subsection{Forecast}

The forecast strategy is the act of predicting or deducing the content of a text by means of the title, typographic clues (illustrations, tables, graphs), the subtitle, among other elements. A title, when well defined, identifies the subject of the text immediately; a photo or a headline on a website can predict the subject of the article.

According to Goodman (1987), reading processing is the same for all languages, that is, readers always use the same strategies mentioned, regardless of the languages they use. In fact, instrumental teaching of foreign languages has already been using this approach to reading with some success, which corroborates its effectiveness in terms of pedagogical intervention to promote the development and improvement of the use of these strategies in reader-learners.

In this reading strategy, the reader must activate the previous knowledge he has on the subject. For example, if the headline of an ad is "Teacher Selection", and the reader identifies the cognate selection and knows the meaning of teacher, it is possible to predict the content of the ad.

\subsection{Inference or Prediction}

In the study of Inference or Prediction, dictionaries are also used. They are important instruments. However, recommended only when a word cannot be understood.

In this reading strategy, the student assumes the meaning of the word by understanding the context (INFOESCOLA, 2020). To this end, the reader must pay attention to the phrase in which the word appears and also consider the sentences before and after.

Inference is also used to decipher messages that are not explicitly expressed in a text. However, the reader should not read word by word, but the whole sentence. For example, analyzing the phrase "An adjective is a word that describes a noun". First, the cognates and the known words are separated: - cognates: adjective (in Portuguese: adjetivo); describes (in Portuguese: descreve); - known words: word (in Portuguese: palavra), is (verb to be in Portuguese: ser ou estar).

Initialized the translation in Portuguese: adjetivo é _ palavra descreve 


\section{2nd World Conference on Teaching and Education}

By inference, the sentence is completed: "Um Adjetivo é uma palavra que descreve um substantivo".

To suppose the meaning of the word "noun", the reader needed to know the concept of adjective. Note that there was no need to "guess" the word an at the beginning of the sentence.

\subsection{Selectivity}

Selectivity is a reading strategy widely used in reading technical texts. This strategy consists of identifying the paragraph in which the desired information is found.

Through this strategy, the reader can distinguish between the main idea and the secondary idea. Therefore, it is not necessary to understand the entire text to get a general idea of it.

The reader must select the keywords, those that repeat the verbs or contextual references. Unknown words then need to be translated with the help of the dictionary. For example, when faced with a text, the typographic clues are observed and hypotheses are created about its content.

\section{Steps to good reading}

Notes can be made in the text, underlining: - cognate words; - those that are repeated; - the known words. Unknown words can be circled and the reader can try to infer their meanings from the context, as identical words can have different meanings.

Any student has the ability to be able to "read" in English, or better, at least understand the main points. English reading is a skill that can be developed in a relatively short time. The recommendation is to combine the use of reading techniques and strategies in English in order to extract information from the text.

It is also necessary that the student tries to learn some basic verbs and words (verb To Be, pronouns, regular verbs, basic nouns, etc.). In this way, you will be able to understand the texts more efficiently, thus improving your reading in English. The use of grammar will also help a lot.

\subsection{Example of the use of reading techiniques and strategies}

When the student is faced with an English text, they must use the reading techniques and strategies to achieve the objective, whether it be answering questions related to the text, translating some paragraphs, extracting the central idea of the text, summarizing the text among many other activities (ROBINSON, 1980).

To exemplify the use of techniques and strategies, Activity 1 presents a text and some questions to be answered after the explanation of some reading techniques and strategies, by the students of the second year of the technical course of information technology integrated to high school. 


\section{2nd World Conference on Teaching and Education}

What are computers?

Computers are machines that perform tasks or calculations according to a set of instructions, or programs. The first fully electronic computers, introduced in the 1940s, were huge machines that required teams of people to operate.

Compared to those early machines, today's computers are amazing.

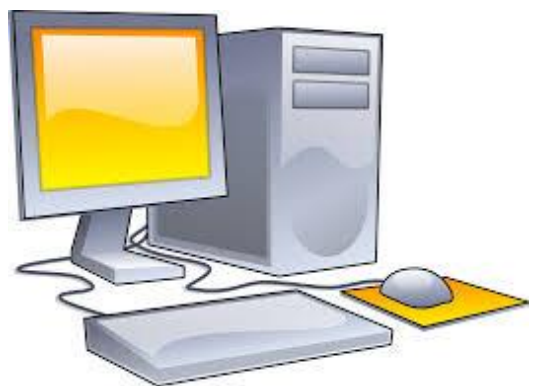
Not only they are thousands of times faster, they can fit on your desk, in your lap, or even in your pocket.

Computers work through an interaction of hardware and software. Hardware refers to the parts of a computer that you can see and touch, including the case and everything inside it. The most important piece of hardware is a tiny rectangular chip inside your computer called the central processing unit (CPU), or microprocessor. It's the "brain" of your computer- the part that translates instructions and performs calculations.

Answer the questions related to the text, in Portuguese.

1. What are computers?

2. What were electronic computers like in the 1940s?

3. What is the most important piece of hardware?

Activity 1: What are computer?

For each question, some techniques and strategies that were used to elaborate the answer are presented.

Question: 1. What are computers?

Techniques and strategies used:

- prediction searching in the text, the title and figures to predict the subject of the text;

- scanning looking for the answer to the question: first paragraph.

- identification of the cognates of the paragraph or part of it, where is the answer to the question:

"Computers are machines that perform tasks or calculations according to a set of instructions, or programs."

In Portuguese: Computadores máquinas calculos acordo instruções, _ programas.

- identification of known words, especially the verb to be (to be);

- contextual reference, adding articles, prepositions, conjunctions to make sense of the sentence;

- inference, "guessing" words to complete the sentence, giving meaning to the subject. 


\section{2nd World Conference on Teaching and Education}

19-21 February, 2021

Vienna, AUSTRIA

Answer: Computadores são máquinas que desempenham cálculos de acordo com instruções e programas.

Question: 2. What were electronic computers like in the 1940s?

Techniques and strategies used:

- scanning looking for the answer to the question:

"The first fully electronic computers, introduced in the 1940s, were huge machines that required teams of people to operate."

- identification of the cognates of the paragraph or part of it, where is the answer to the question:

Cognates: eletronic computers appear, the answer is after the year 1940. Therefore, it remains only: "were huge machines that required teams of people to operate."

In Portuguese: máquina requer para operar.

- identification of known words, mainly verbs;

- contextual reference, adding articles, prepositions, conjunctions to make sense of the sentence;

- identification of the keyword, which can be translated using the dictionary (huge: huge, immense)

- inference, "guessing" words to complete the sentence, giving meaning to the subject.

Answer: Eram máquinas enormes que requeriam (ou precisavam) pessoas para operá-las.

Question: 3. What is the most important piece of hardware?Techniques and strategies used:

- scanning looking for the answer to the question:

"The most important piece of hardware is a tiny rectangular chip inside your computer called the central processing unit (CPU), or microprocessor"

- identification of the cognates of the paragraph or part of it, where is the answer to the question:

In Portuguese: retangular chip processamento unidade $\overline{(\mathrm{CPU}), \ldots \text { microprocessor }}$ computador central

- nominal group: (rectangular chip); (Central Processing Unit);

- identification of known words, mainly verbs;

- contextual reference, adding articles, prepositions, conjunctions to make sense of the sentence;

- identification of the keyword, which can be translated using the dictionary (tiny: very small) 


\section{2nd World Conference on Teaching and Education}

\section{9-21 February, 2021 Vienna, AUSTRIA}

- inference, "guessing" words to complete the sentence, giving meaning to the subject.

Answer: É um chip retangular muito pequeno dentro do computador denominado unidade central de processamento.

Answers do not need to be translated word by word. However, they need to make sense.

\section{Methodology}

The teaching of English with the use of reading techniques and strategies took shape from the development of face-to-face classes, with activities in pairs and individuals, aiming at the development of reading and text comprehension skills, in the perspective of instrumental English. In this case, the teacher plays the role as a facilitator in the process of joint construction, as he accompanies and assists the student until he takes responsibility for his development, demonstrating that he is able to carry out the activities autonomously. Teaching stops prioritizing grammar to work with the text, without abandoning it. Grammar is approached in a contextualized way, helping to understand academic texts. Vocabulary, in turn, is related to the student's area of study.

To effect the use of reading techniques and strategies in the teaching of the English language, a survey and reading of several works, articles and experience reports on the use of reading techniques and strategies in the teaching of foreign languages were carried out, aiming at deepening the techniques and reading strategies based on existing studies in an instrumental approach. Then, the classes were structured, using reading techniques and strategies, involving grammar and contextualized vocabulary. In all classes, activities were proposed, with punctuation, in order to motivate participation avoiding absences.

For the selection of texts, a diagnostic evaluation was made to the students. At the beginning of each class, the teacher explained the purpose of the class and what activity they should do and how. At the end of each class, the teacher collected the activities, made the correction later, and recorded some information about the meeting, such as, for example, the participation of the student; learning gains; what are the biggest difficulties; whether the text could be more extensive or involving more vocabularies; among other records.

Thus, at the next meeting, he would deliver the duly corrected activity and depending on the performance, he would advance to the next reading technique or strategy or keep it for the benefit of the class.

\section{Conclusion}

Of the four skills to be developed by the student (reading, writing, listening and speaking), reading is the one highlighted in this work, as it is fundamental for the development of other skills. It is known that most people have difficulties in reading an English text, either due to lack of knowledge, practice or even the desire to learn and, consequently, to read. Regardless of the reason, it is important to know that there are techniques and strategies that can assist in reading an English text.

The main objective of this work was to present some techniques and strategies in the teaching of the English language that are being made available to high school students, based 


\section{2nd World Conference on Teaching and Education}

on English for Specific Purposes (ESP). For example, when searching for information, one should use the scanning technique for a specific word; when a document is explored or revised, the skimming technique must be used; if the person needs to write an opinion on a certain text, it uses critical reading and so on.

The results show that the instrumental approach can be a differential in the students' learning, since it works according to the needs and interests of each one, whether to read or interpret a text, understand a film, know the lyrics of a song, answer questions in the entrance exam, remove errors from programs on the computer, etc.

It is worth mentioning that teachers need opportunities to reflect on their teaching and must update themselves according to the position of importance that the English language plays in the education of students so that they become citizens prepared to deal with demands of the academic and professional world.

Through this article we hope to contribute to the teaching of the English language by trying to briefly present the reading techniques and strategies.

Finally, a survey of the maximum possible questions to be addressed in later studies should be made as a way of encouraging the study and research of the use of reading techniques and strategies in teaching not only the English language, but foreign languages, involving the four skills (reading, writing, listening and speaking).

\section{References}

Bendito Inglês. Técnicas de leitura em inglês para estudantes melhorarem o reading. Disponivel em: http://benditoingles.com.br/tecnicas-de-leitura-em-ingles $>$. Acesso em 10 abr. 2020.

BRASIL. (PCN) + Ensino Médio: Orientações Educacionais Complementares aos Parâmetros Curriculares Nacionais. Volume Linguagens, Códigos e suas Tecnologias. Brasília: SEMTEC, 2002.

CELANI, M. A. A.et al. The Brazilian ESP Project: an Evaluation. São Paulo: EDUC, 1988.

CIOCARI, R. M. Apostila de Inglês Instrumental 2011/2. Disponível em: <http://tics.ifsul.edu.br/matriz/conteudo/disciplinas/_pdf/ingles_instrumental.pdf>. Acesso em 04/05/2020.

ESTRATÉGIA VESTIBULARES. Scanning e skimming. Disponível em: https://blog.estrategiavestibulares.com.br/scanning-e-skimming/. Acesso em 01 jun. 2020.

FREIRE, O. A importância do ato de ler: em três artigos que se completam. São Paulo: Cortez, 1988.

GOODMAN, Kenneth. 1987. O processo de leitura: considerações a respeito das línguas e do desenvolvimento in: Ferreiro, Emília. et al. (eds.). Os processos de leitura e escrita: novas perspectivas. Porto Alegre: Artes Médicas. p. 11-22.

INFOESCOLA. Técnicas de Leitura e Compreensão de textos em Língua Inglesa. Disponível em: $\quad$ https://www.infoescola.com/ingles/tecnicas-de-leitura-e-compreensao-de-textos-emlingua-inglesa/. Acesso em 29 mai. 2020. 


\section{2nd World Conference on Teaching and Education}

INGLÊS 200H. Prefixos e sufixos em inglês: como usá-los corretamente? Disponível em: https://ingles200h.com/prefixos-e-sufixos-em-ingles/. Acesso em 02 abr. 2020.

JACOBS, Michael Anthony. Como melhorar ainda mais seu inglês. Rio de Janeiro: Ed. Campus, 2003.

LIMA, D. C. Ensino Aprendizagem de língua inglesa: conversas com especialistas. In Aquisição de leitura em língua inglesa. Parábola Editorial: São Paulo, 2009. p. 195 -196.

MUNDO VESTIBULAR. Técnicas de leitura em inglês. Disponível em: https://www.mundovestibular.com.br/estudos/ingles/tecnicas-de-leitura-em-ingles>. Acesso em 20 abr. 2020.

OLIVEIRA, S. M. B. C.; ROLIM, J. K. H. Inglês instrumental eixo Informação e Comunicação. Teresina, PI: Instituto Federal de Educação, Ciência e Tecnologia do Piauí, 2012.

ROBINSON, P. ESP - English for Specific Purposes. Pergamon Press, 1980.

SANTORUM, Karen; SCHERER, Lilian Cristine. O papel do ensino de estratégias para o desenvolvimento da leitura em segunda língua (L2). Revel. Vol 6, 2008, p. 100. 